\title{
Semiotic Analysis of Space and Time in the Film
}

\author{
Wantoro \\ Visual Communication Design Program \\ Universitas Komputer Indonesia \\ Bandung, Jawa Barat - Indonesia \\ wantoro@email.unikom.ac.id
}

\begin{abstract}
Time Machine is a science-fiction film produced in 2002, which is an adaptation of the same novel titled HG Wells written in 1895. Time Machine film tells of a scientist, and inventor named Alexander Hartdegen living in Manhattan, New York who is determined to prove that time travel is something that is possible to do. The determination to make the journey across time itself is caused by the despair of the past personal tragedy that prompted him to change the past. Through testing a number of theories ultimately Hartdegen found the time machine and can travel time began to return to his past until gliding into the next 800,000 years and find new reality and new realities that are much different from his time. In this research, the writer will review and analyze Time Machine film through semiotic method, especially Space and Time Semiotics. In the application, the author will select some scenes in the film to be analyzed. This research is important to do as an effort to know the existence of space and time as a marker and marker in a film work.
\end{abstract}

\section{Keywords-Semiotic, Space, Time, Film, Machine}

\section{INTRODUCTION}

Film is a form of narrative that is built by sequences of scenes that form a story. As a product of popular culture, film is one of the favorite pastimes of the people. Films usually tell things that have happened or will happen. The telling of time in the film can be through forward or backward grooves. Some films even directly tell things in the past and in the future through a combination of back and forth grooves.

One film that tells the past and the future is a Time Machine. This film is a science fiction film produced in 2002 and is an adaptation of the same titled novel by HG Wells (1895) published by the publisher William Heinamann.

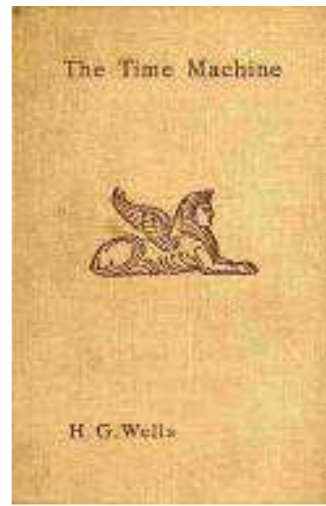

Fig. 1. First Edition Cover Novel Time Machine
Time Machine film tells the story of a scientist and inventor named Alexander Hartdegen (played by Guy Pearce) who lives in Manhattan, New York who is determined to prove that time travel is something that is possible to do.

Determination of traveling across time alone is caused by a desperate attitude because of a bad personal tragedy in the past that encouraged him to change the past. The bad tragedy was the death of her lover named Emma who was shot by a robber in 1899 in a park. Through testing a number of theories, Hartdegen finally found a time machine that could travel time back to its past. Not only in the past, the time machine can also bring it to the next few years like 2030, 2037 to 800,000 years into the future, where it finds reality and new realities that are far different from its time. This film is very interesting to watch because there are many leaps of space and time.

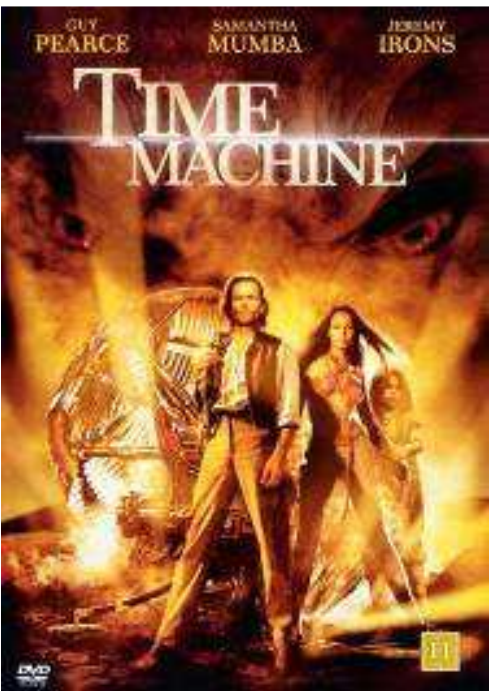

Fig. 2. Time Machine Film Poster

The article, entitled "Semiotic Analysis of Space and Time in the Time Machine", will analyze the phenomenon of space and time experienced by Alexander Hartdegen. A journal entitled "Perjalanan Fantasi Menembus Ruang dan Waktu" written by Sudjadi Tjipto R [1], actually raised the same thing. But in the journal, the research only focuses on the space and time that occurred in 2030 and did not elaborate on the overall flow of the film. In addition, research on time space that is a reference is research conducted by Siswanto [2], and Tandyonomanu \& Bahfiarti [3]. This research will use semiotics methodology specifically related to space and time. It is hoped that with this methodology, it can be seen how Time Machine's film as a narrative builds messages from many 
spatial signs and phenomena and their relationship to the phenomena of life today. Some other studies on films that use semiotics include Roszainora with the title Semiotic Analysis of a Media Text of The Lord of the Rings: The Fellowship of the Ring published by Canadian Social Sciences Vol. 5 No.4 2009 [4]. and Alvior [5]. titled Semiotic Analysis on James Cameron Selected Science Fiction Movies.

\section{METHOD}

In this study, the author will use semiotics. The word semiotics comes from the Greek, which is "Semeion" which means sign. Semiotics itself is a study of a sign. Semiotics is the study of signs and the way the sign works (John Fiske, 2007). Semiotics studies systems, rules, conventions that allow signs to have meaning. Understanding the sign itself is something that can conventionally replace or represent something else. According to F. de Saussure, the sign has 2 (two) entities namely signifier (sign) and signified (sign) or means of sign and meaning [6]. The relationship between the marker and this marker is arbiter (free). In general, semiotics is divided into 3 basic concepts, namely pragmatic semiotics (describing the origin of the sign, the sign function by the implementer, and the effect of the sign for interpreting, within the limits of subject behavior), synthetic semiotics (describing the combination of signs without regard to their meaning or relationship towards subject behavior) and semantic semiotics (describing the meaning of a sign according to the 'meaning' conveyed). Semiotics, as a sign of science, was chosen as a methodology for analyzing Time Machine films because in general films were designed with several signs. These signs work together in an effort to achieve the expected impact by the filmmaker in the form of a specific message to the audience.

The first stage in this study was to collect data in the film of "Time Machine" (2002) produced by DreamWorks \& Warner Bross Pictures. The first approach is observation or direct observation of Time Machine films by watching it. In observation or direct observation, researchers will record and record some important things in the film. Researchers will also document several important scenes by capturing them. The next approach used is literature study. Literature study is the study of data collection using media such as books, articles and scientific research on the design of visual communication, films, signs and related research methodologies. Some articles from related print and internet media sources are also used. After data is collected, the next step is to process data by selecting, classifying and preparing data. At this stage, the writer will choose several scenes that represent space and time marks in the film. The selected scene will be analyzed in the next stage. [7]

The film analysis process will be carried out by identifying changes in space and time markers in several scenes. Changes in time and space will arise from the visual differences that arise where the figure (Alexander Hartdegen) is like architecture, life, and so on. Visualization of space and time is a representation of the era visited by Alexander Hartdegen using the time machine he made[8]. The author will select several scenes selected from the film. After the object data is analyzed, and obtained temporary results, the next thing to do is to check the validity of the results. The purpose of this is so that the research carried out results in objective and scientific data, so that results can be accounted for and useful.

\section{RESULTS}

Time Machine is a film (narration) that presents several different space and time settings. This is because the main characters in the film make several time trips for both the future and the past. The story of time travel itself began when Alexander Hartdegen (the main character \& inventor of the time machine) made his first trip back to the past 1899 (4 years back) using a time machine from his findings from his office in Manhattan, New York. to correct a grim story about the death of her lover Emma. [9]

Unfortunately, Alexander Hartdegen's efforts were in vain because it seemed destiny could be changed and his lover still died in a different way (hit by a train)[10]. This tragic event made Hartdegen look for answers to the death of his lover by sliding into the future (in 2030) with his time machine. In 2030, he sought information in the City Library of New York and met with Vox 114 (Orlando Jones) a human form of holographic library guard who explained that attempts to break through time to change historical destiny were impossible. Not quite satisfied with the fact Alexander explored the time until 2037 when the condition of the earth was almost damaged by the moon which exploded because of the human colonies that inhabited it[11]. In an attempt to save him, he was accidentally thrown in 802701 years after the incident and saw the fact that a new evolution on earth had taken place, giving rise to two remaining humans, namely Eloi who lived on the ground and Morlock who lived on the stomach[12]. The decision to destroy Über-Morlock and the cannibal monsters that eat humans was done by destroying the time machine, this effort was made to make the history of the new Eloi human civilization even better. At the end of the film Alexander was told that he finally settled in the primitive era and intended to rebuild his research laboratory.

Based on film analysis, the following results are obtained:

\section{A. Use of Time Machine Technology}

Conflicts and achievements in this film were caused by the use of time machine technology created and used by the main character, Alexander Hartdegen. The time machine in this film acts as a medium for leaping space and time to change the situation.

\section{B. Space Change}

In Time Machine, there are some changes in the dimensions of space. Space changes occur due to space jumps when characters leap from one time to another $(1899,1903$, 2030, 2037, 802.701 and 635.427.810) using a time machine. Markers of changing time settings are known through markers that look like buildings, environment, weather, and so on.

\section{Time Change}

In this film there are some changes in time settings because of the time jump from one time to another. Markers of changing time settings are known through visible markers such as numbers, technology, life culture artifacts and so on.

\section{DISCUSSION}

In a previous study conducted by Sudjadi (2015), it was revealed that in each shot of the film The Time Machine there 
was reality and imagination deliberately combined so that the science fiction stories compiled by the director looked scientific. Some eleman shot machines with time bubbles, visible horizon lines, and the life of a new human colony on the moon are basically false imaginations of space and time.

\section{A. 1899}

In 1899 was the year the film began. This year, the main character Alexander Hartdegen plans to propose his girlfriend Emma in a park. Unfortunately, at that time the two were robbed. The robbery resulted in the death of Emma who tried to defend the fiance ring given by Alexander Hartdegen.

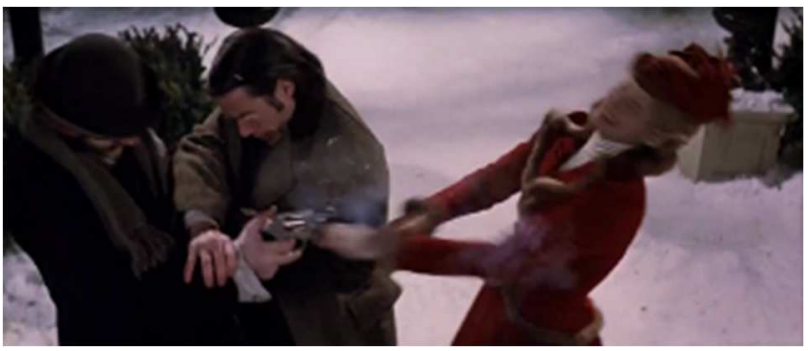

Fig. 3. Emma was shot by a robber in a park

In the end, Emma's death made Alexander Hartdegen's life change and became a starting point for conflict in this film.

\section{B. 1903}

Four years after Emma's death, a time machine created by Alexander Hartdegen as an attempt to return to 1899 was created to change the fate of his lover's death. A time machine consisting of chairs and numbers is created with full confidentiality..

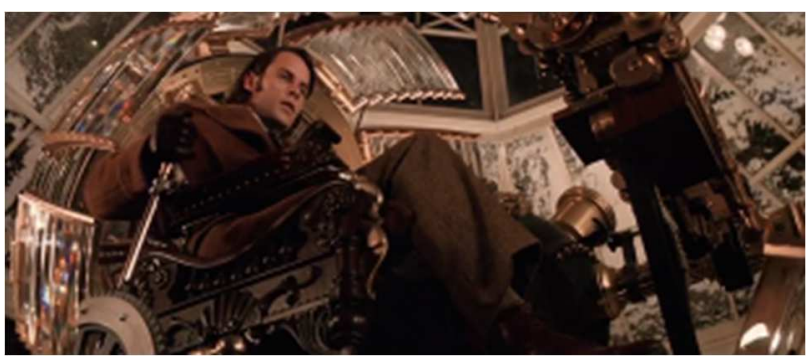

Fig. 4. Alexander Hartdegen with Time Machine

When the first time the engine is used, the camera frame highlights a classic clock whose clock rotates rapidly backwards.

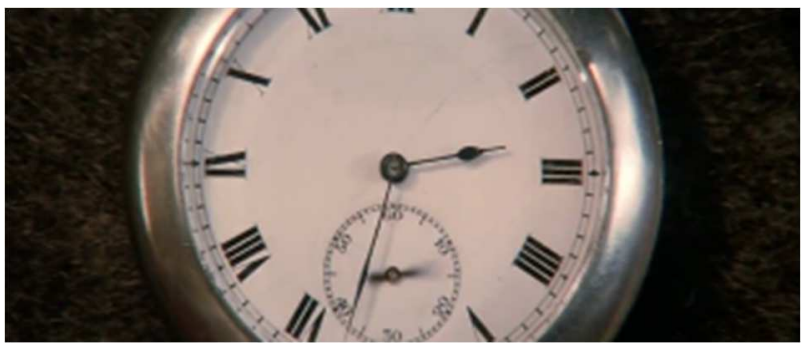

Fig. 5. Illustration when goes back to 1899

It also looks at the time-numbered machine in the setting to go back to 1899 .

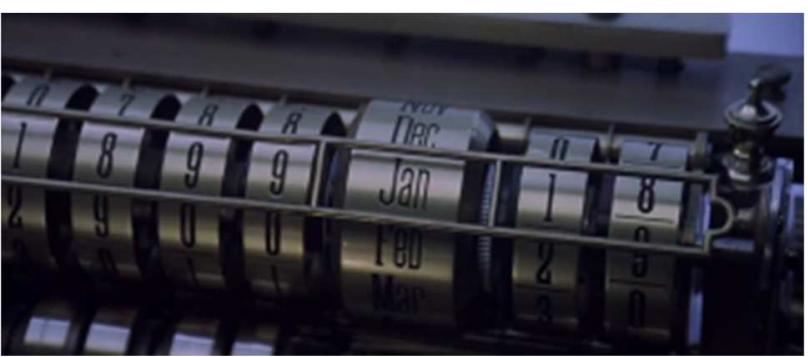

Fig. 6. Numbers on a Time Machine

Alexander Hartdegen managed to return to the time when he could meet his girlfriend again and avoid the robbery in the park. Unfortunately, Emma's destiny could not be changed where she was still hit by a train.

\section{1899 to 2030}

Emma's death for the second time disappointed Alexander Hartdegen. He decided to go to the future where he tried to find answers to destiny there. When Alexander Hartdegen headed for the future using a time machine, there was a change around it. One sign of change is the spider web that is seen interwoven around the machine.

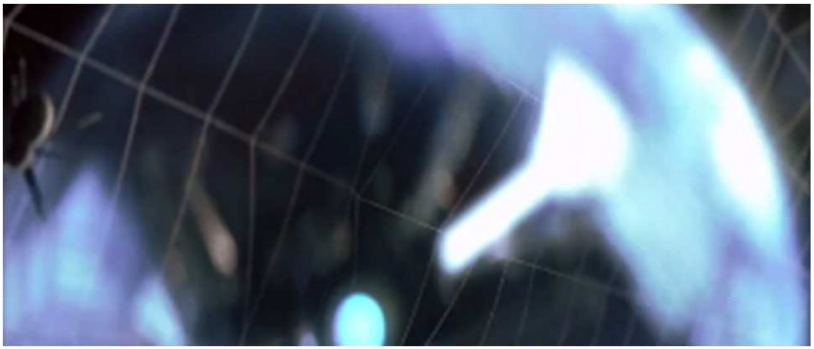

Fig. 7. Spiders that build their nests

In addition, the camera also highlights the changing shape of the city to modern and sophisticated. This can be seen from the sign of the emergence of tall buildings and airplanes.

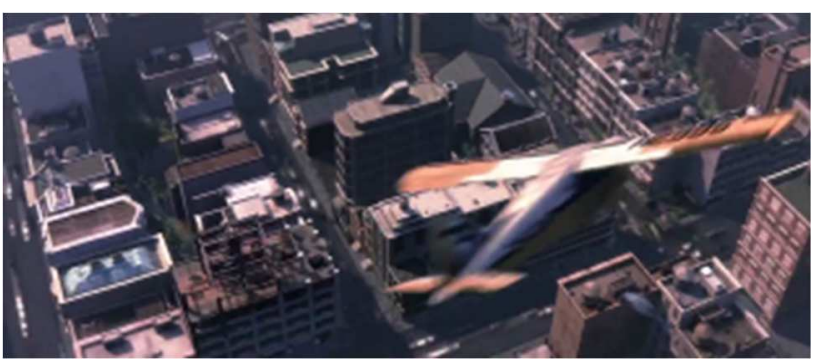

Fig. 8. Illustration of changes in the shape of the city

\section{2030}

When Alexander Hartdegen and his time machine landed in 2030, it was seen how environmental changes occurred. This was further strengthened by the sign of the emergence of digital billboards with the words "The Future is Now". 


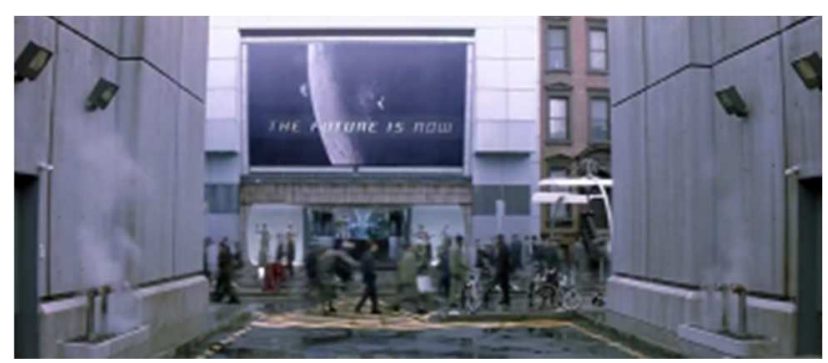

Fig. 9. Alexander Hartdegen arrived in 2030

Buildings in 2030 also look more minimalist and modern. Very busy human life is also raised with the crowds of people who walk and use bicycles in their activities.

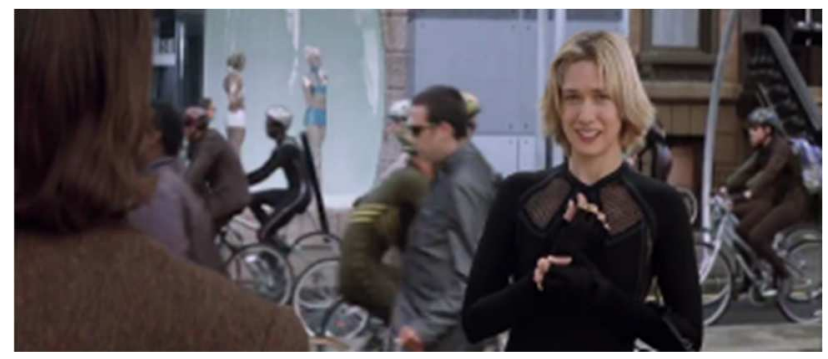

Fig. 10. Differences in clothing with the earth's community in 203

Another thing that marks the time difference between Alexander Hartdegen and the people at that time was clothing. Public clothing in 2030 is more minimalistic and functional than what is worn by him. This is also reinforced by conversations in the film.

\section{E. 2037}

The space travel of Alexander Hartdegen, which continued to 2037 , led to a state of war. This is marked by the condition of the city being destroyed with cars and buildings damaged and burned.

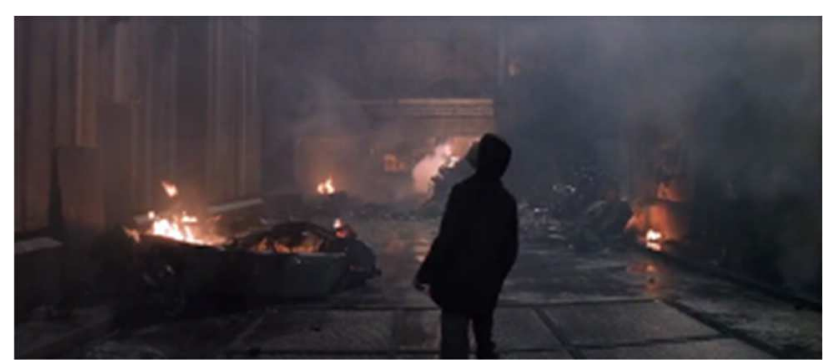

Fig. 11. Alexander Hartdegen arrived in 2037

\section{F. 2037 to 802.721}

To avoid the war, Alexander Hartdegen hurried away with his time machine. Unfortunately his journey to the future became unsuccessful because the time machine he created could not be controlled. Alexander Hartdegen went too far into the future in 802,721 .

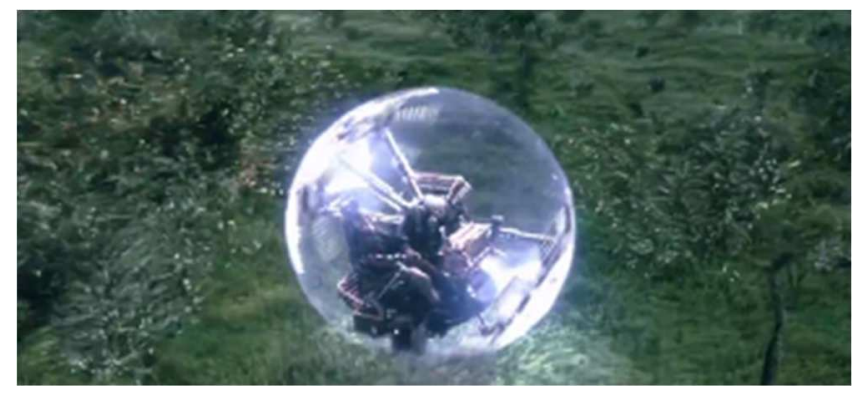

Fig. 12. Time Machine from 2037 to 802,721

The journey of time that is too far results in the visualization of extreme changes in the environment around the time machine. Changes are marked by the growth of trees, climate change, changes in topography of the earth and so on.

\section{G. 802.721}

The journey of the main character up to the year 802.721 was marked by the numbers on the time machine he made.

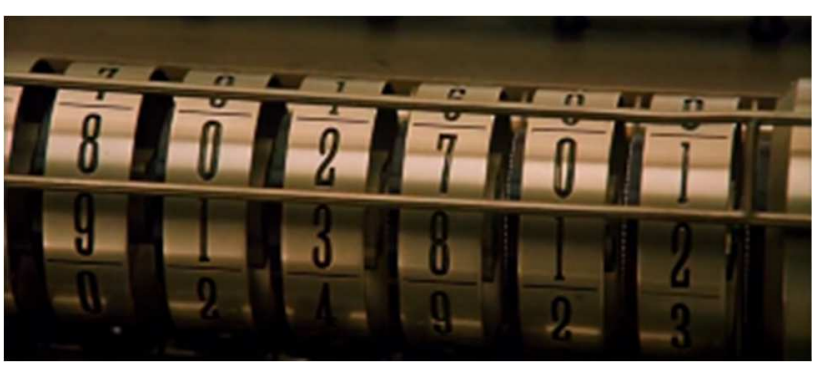

Fig. 13. Alexander Hartdegen arrived in 802.701

But the time travel that was too far and great made him unconscious. When he realized, he found that he had been in a community called Eloi with the uniqueness of the house he lived in. In addition to buildings, the Eloi community also uses clothes and language that have actually been past.

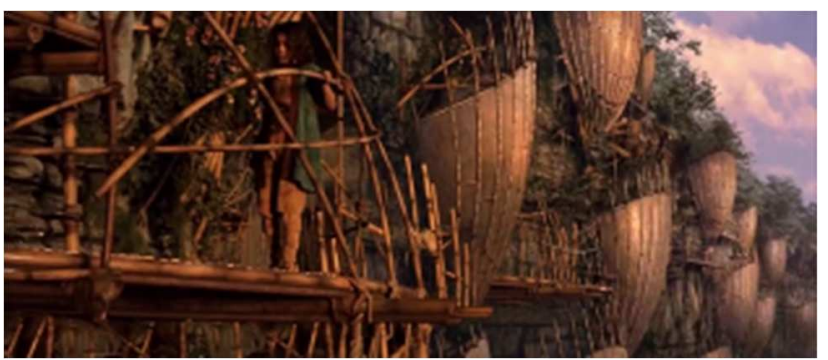

Fig. 14. Eloi Community Building

At this time, Alexander Hartdegen became acquainted with Mara. Mara is a woman who finds herself and her time machine. Besides Emma, he also met with Kalen and the entire population of Eloi. Unexpectedly, the Eloi community turned out to store past artifacts in the form of building inscriptions containing the letters of the building's name. Alexander Hartdegen's encounter brought him to remember the past he had passed. 


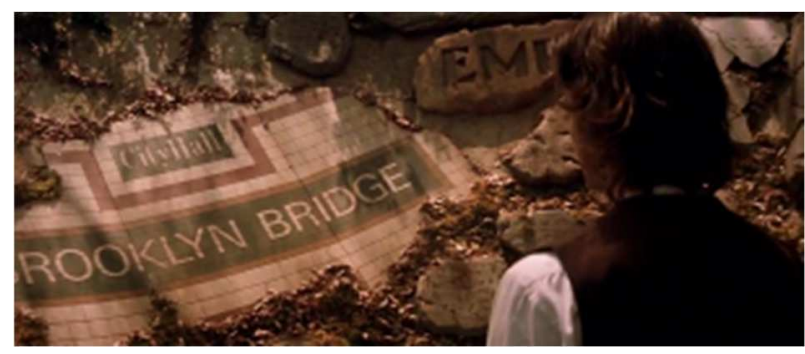

Fig. 15. Eloi Community Building

On the other hand, the Eloi community turned out to face threats from the Marlock people who kidnapped and preyed on it. In this condition, Alexander Hartdegen finally intended to help and fight the Marlock nation. The only way he can do is to use a time machine.

\section{H. 635.427 .810}

To change the fate that occurred in 802,721 , Alexander Hartdegen slid into the future to see what happened using his time machine. As a result of an increasingly uncontrollable time machine, he reached the year $635,427,810$ but in the same space.

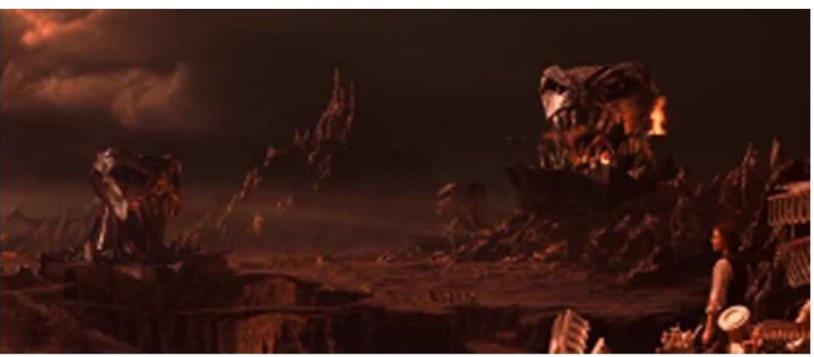

Fig. 16. The condition of the earth in the year H. $635,427,810$

In that time and space, he saw the destruction that occurred at the Murlock nation's headquarters. This can be seen from the visual sign of the destruction of the place.

\section{Time Machine Ends}

To change destiny and destroy the Murlock nation, Alexander Hartdegen was forced to destroy the time machine. The destruction of a time machine is characterized by a great light explosion.

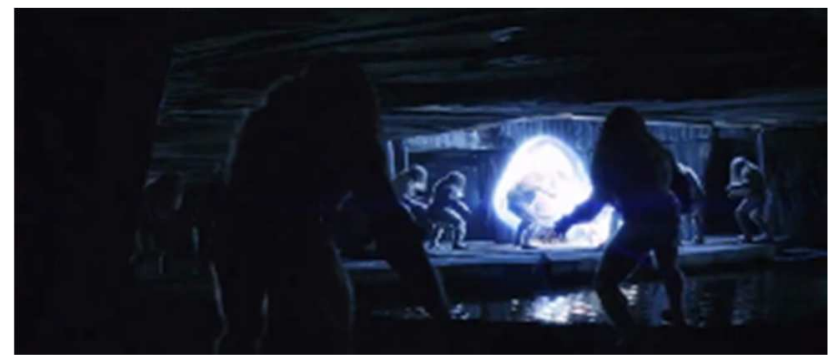

Fig. 17. Destruction of time machines

After the destruction of the Murlock nation and the engine of his creation, Alexander Hartdegen decided to remain in his future with Mara and the Eloi community. At the same time and place, colleagues (Mr. Philby) and Mrs. Watchit are worried about their existence.

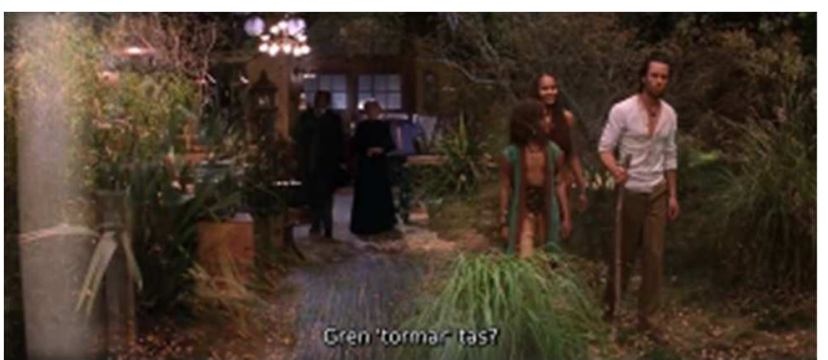

Fig. 18. Two times running together

Two places and times that run together are marked by the division of the film visualization frame in two different scenes.

\section{CONCLUSION}

Time Machine film clearly demonstrates a time machine tool born of ratio and intellect. With this tool, the main character (Alexander Hartdegen) can determine the direction of space, time and destiny according to his wishes. Through this Time Machine film, the maker (who in fact the United States, as the originator of modernism) seems to want to spread the view that ratio, intellectuality, science are the only means to progress. The aim was to persuade all spectators to agree to this view, so that universalism as one of the characteristics of the modernist narrative was achieved. The marker of the message is a time machine with all its capabilities. Of course, in the film all of them are designed and presented very implicitly using visual signs so that the audience does not feel like being patronized, indoctrinated or influenced. This is all in order to facilitate the delivery of the message slowly and embedded in the minds of the audience. The message in this film shows the desire of US power (in general the West) that never ends. Human desire by relying on the advancement of science technology that continues to be developed today to penetrate space and time to change history. History according to them is true, in accordance with their expectations not just destiny. Humans the greater the desire to correct history, change the destiny that has happened as played by Alexander Hartdegen when he wants to change the destiny of the death of Emma, his lover. This desire finds distribution in the film media, because with the film everything has not been achieved can be projected easily, quickly and possible.

\section{ACKNOWLEDGMENT}

Praise \& thank to Allah SWT, so that the writer can finish this article. The author also thanked: UNIKOM Chancellor Assoc. Prof. Dr. Ir. H. Eddy Soeryanto Soegoto, Dean of the Faculty of Design at UNIKOM Prof. Dr. Yusuf Affendi Djalari, DKV Staff and lecturer and UNIKOM Directorate General and UNIKOM ICOBEST Team. Finally, the authors realize that this article is still lacking. Therefore, the authors ask for constructive suggestions and criticisms. Hopefully this article will benefit us all.

\section{REFERENCES}

[1] Tjipto, Sudjadi. (2015). Perjalanan Fantasi Menembus Ruang dan Waktu. Jurnal Rekam : Yogyakarta.

[2] Siswanto, Joko. (1989). Laporan Penelitian Konsep Ruang Dan Waktu Dalam Filsafat Barat. Universitas Gadjah Mada 
[3] Tandyonomanu, Danang \& Bahfiarti, Tuti. (2013). Seni Ruang dan Waktu dalam Mappacci Pada Upacara Perkawinan Adat Bugis. Universitas Negeri Surabaya \& Universitas Hasanuddin Makassar.

[4] Setia, Roszainora. (2009). Semiotic Analysis of a Media Text The Lord of the Rings : The Fellowship of the Ring. Canadian Sosial Sience Vol.5 No.4.

[5] Emberga, Gerald Alvior . (2016). Semiotic Analysis on James Cameron Selected Science Fiction Movies. Central Mindanao University, Musuan, Maramag Bukidnon.

[6] Noth, W. (1995). Handbook of Semiotics. Bloomington: Indiana University Press.

[7] Adam, Barbara (1998). Timescapes of Modernity: The Environment and Invisible Hazards. London : Routledge.
[8] Amir Piliang, Yasraf. (2004). Dunia yang Dilipat: Tamasya Melampaui Batas-batas Kebudayaan. Jalasutra : Yogyakarta

[9] Bard, Alexander \& Soderqvist, Jan.(2002). Netocracy: The New Power Elite and Life After Capitalism. Great Britain : Pearson Education.

[10] Gleick, James. (1999). Faster: The Acceleration of Just About Everything. New York : Hachette Book Group.

[11] Levebfre, Henry. (1991). The Production of Space. Oxford : Blackwell Publisher Ltd.

[12] Prasetia Tugas Jaya, Eka. (2016). Analisis Semiotika Film 99 Cahaya di Langit Eropa. Universitas Pasundan : Bandung 